\title{
Hallinnon Tutkimus -lehti tieteenalan näkyvyyden ja vaikuttavuuden edistäjänä
}

$\mathrm{H}$ allinnon Tutkimus -lehden toimitus on siirtynyt Itä-Suomen yliopistosta Tampereen yliopistoon vuoden 2019 alusta. Olemme kiitollisia aiemman toimituksen työstä ja otamme toimituksellisen kapulan vastaan seuraavaksi kolmeksi vuodeksi nöyrin mielin. Hallinnon Tutkimus -lehdellä on pitkät ja kunniakkaat perinteet suomalaisen hallinnontutkimuksen julkaisukanavana, ja näitä perinteitä haluamme myös me toimituksena vaalia. Ollakseen laadukas julkaisukanava perinteiden vaalimisen ohella lehden muotoa, sisältöä ja toimitusprosessia on kuitenkin jatkuvasti kehitettävä vastaamaan ajan tarpeita. Tämä uuden toimituksen yhteisesti kirjoittama ensimmäinen pääkirjoitus on varattu näiden kehitystoimenpiteiden esittelyyn.

Edellisen toimituksen aikana aloitettu lehden sähköistäminen tullaan viemään loppuun kokonaisuudessaan kuluvan vuoden aikana. Artikkelikäsikirjoitusten lähettäminen ja arviointiprosessin käsittely siirtyvät Journal.fi-palveluun tulevan kesän aikana. Tällä nopeutetaan toimitusprosessia ja parannetaan käsikirjoitusten arvioinnin aikatauluja. Myös tänä keväänä ilmestyvät lehdet $1 / 2019$ ja $2 / 2019$ löytyvät mainitusta palvelusta viimeistään kesän jälkeen. Lehden aiemmat numerot vuodesta 1982 alkaen on skannattu ja ne viedään Journal.fi-palveluun sitä mukaa kun hyväksyntä sähköiselle julkaisemiselle artikkelien kirjoittajilta saadaan varmistettua. Hallinnon Tutkimuksen Seuran johtokunta (joka toimii samalla lehden toimituskuntana) tulee tekemään lehden sähköistämiseen ja ns. embargoaikaan liittyvät päätökset. Avoimen tieteen periaatteiden mukaisesti lehden artikkelien post-print -versiot (lopulliset versiot ennen taittoa) voidaan jatkossa useimpien muiden lehtien tavoin rinnakkaistallentaa julkaisuarkistoihin ilman erillistä lupaa toimitukselta.

Lehden toimituksellisia prosesseja terävöitetään ja sujuvoitetaan monin tavoin. Toimitukselle toimitettujen artikkelien läpimenoaikaan kiinnitetään erityistä huomiota seuraamalla tarkasti sekä arvioinneille että revisioille annettujen määräaikojen noudattamista. Myös tähän Journal.fi -palvelu antaa mm. muistutusviestien automatisoinnin takia nykyistä paremmat edellytykset. Lähdeviittauksissa siirrytään APA-standardin (6th edition tai uudempi) noudattamiseen pääosiltaan. Tämä helpottaa $\mathrm{mm}$. viitteiden hallintaohjelmistoja (EndNote, Mendeley, RefWorks yms.) käyttäviä kirjoittajia, joiden ei tarvitse standardiviittauksissa muokata manuaalisesti viitteitään.

Tieteellisten lehtien sisäisen laadunvarmistuksen luovuttamaton edellytys on puolueeton ja kattava arviointiprosessi, joka toteutetaan poikkeuksetta sekä kirjoittajan että arvioitsijan anonymiteetin varmistavalla ns. tuplasokko-menetelmällä. Laadukas arviointi ei ole mahdollista ilman motivoituneita ja asiansa osaavia vertaisarvioitsijoita. Lehden arvioitsija- 
poolia on tästä syystä jo tämän toimituksen ensimmäisinä kuukausina tietoisesti laajennettu, jotta arvioinnin työtaakkaa voidaan jakaa tasaisemmin. Toistaiseksi suostumuksia arvioitsijaksi ei ole ollut vaikeaa saada muutamia yksittäisiä poikkeuksia lukuun ottamatta. Tästä olemme kiitollisia, ja toivomme jatkossakin niin uusilta kuin vanhoilta arvioitsijoilta positiivista suhtautumista tähän tehtävään kutsuttaessa. Samalla myös arviointikäytäntöihin liittyvään läpinäkyvyyteen ja tilastointiin kiinnitetään jatkossa entistä tarkempaa huomiota. Jatkossa kunkin kalenterivuoden lopussa lehden toimituskunta esittelee seuran johtokunnalle keskeiset artikkelien arviointiin tunnusluvut, joiden avulla voidaan seurata lehden vetovoimaa ja selektiivisyyttä. Keskeisimmät tunnusluvut julkaistaneen myös lehden verkkosivustolla. Toivomme, että tunnuslukujen julkistaminen ja lehden toiminnan läpinäkyvyys viestittävät lehden laadusta, käsikirjoitusten volyymistä ja prosessien korkeatasoisuudesta. Tästä syystä niiden julkaiseminen on keskeistä ja tärkeää lehden uskottavuuden kannalta.

Lehti jatkaa julkaisujen aihepiirien ja teemojen osalta varsin eklektisenä, mutta tieteellisiä kontribuutioita tavoittelevana lehtenä. Vaikka lehden pääpaino on julkisen hallinnon ja johtamisen ominaiskysymyksissä, siinä voidaan julkaista myös yrityksen johtamiseen tai ns. kolmannen sektorin organisaatioiden teemoihin kytkeytyviä artikkeleita. Lehdessä julkaistavilta vertaisarvioiduilta artikkeleilta edellytetään, että ne tuottavat uutta tietoa tai uusia näkökulmia käsittelemäänsä aihepiiriin, ja näin osaltaan kontribuoivat aiheesta käytävää tieteellistä keskustelua.

Julkaisukanavien keskinäinen kilpailu laadukkaista artikkeleista on nykypäivänä tunnetusti kovaa. Oman osansa kilpailuun tuo jatkuvasti kasvava julkaisemisen kansainvälistyminen. Tämä on erityisen merkittävä haaste etenkin yhteiskuntatieteellisillä aloilla, jossa kotimaisen julkaisemisen volyymi on JUFO-1 ja JUFO-2 luokissa pienentynyt vuosi vuodelta. Samanaikaisesti kansainvälinen julkaiseminen vastaavissa luokissa on vuosi toisensa jälkeen kasvanut, kuten myös kansainvälisten julkaisukanavien määrä. Kotimaisten tiedelehtien ja muiden julkaisujen ainoa mahdollinen keino vastata tähän haasteeseen on ylläpitää jatkossakin julkaisutoimintansa korkeaa laatua. Hallinnon Tutkimus -lehti on yksi harvoista kotimaisista tieteellisistä julkaisuista jotka yltävät kotimaisten julkaisujen korkeimmalle Julkaisufoorumin luokitustasolle (JUFO-2). Tämä on suuri kunnia, mutta se myös velvoittaa vastuullisuuteen ja lehden jatkuvaan kehittämiseen.

Valitettavasti joudumme päättämään ensimmäisen pääkirjoituksemme suru-uutisella: monien tuntema hallintotieteen kotimainen isähahmo, professori Juha Vartola, menehtyi 30.3.2019 sairauden murtamana. Monille meistä Juha oli kollega, opettaja ja henkilökohtainen tuttava. Kotimaisen hallinnontutkimuksen kehittymisen ja organisoitumisen kannalta Vartolan roolia ja kontribuutiota voidaan pitää valtavana. Hän oli $\mathrm{mm}$. perustamassa Hallinnon Tutkimuksen Seuraa toimien myös ensimmäisenä Hallinnon Tutkimus -lehden päätoimittajana. Lehden ensimmäisen numeron (1/1982) pääkirjoituksessaan Vartola korosti voimakkaasti tarvetta koota yhteen tuolloin eri julkaisufoorumeilla hajallaan ollutta hallintotieteellistä tutkimusta seuraavin sanoin: 
Kuitenkin on niin, että hallinnon tutkimus on nykyisessä tilanteessa liian hajallaan. Hajanaisuus merkitsee yhtäältä sitä, että tutkimusta aktiivisesti seuraamaan pyrkivien olisi pystyttävä seuraamaan (käytännössä tilaamaan) kymmeniä eri aikakauslehtiä ja -kirjoja, toisaalta sitä, että tutkimus "häviää" painopisteiltään muita tieteenaloja ja -kohteita edustavissa konteksteissa. Näin sen näkyvyys ja vaikuttavuus kaikkiaan on suhteellisen epätyydyttävää.

Vaikka Hallinnon Tutkimus -lehti onkin vakiinnuttanut paikkansa hallinnontutkimuksen keskeisenä julkaisukanavana, nämä sanat ovat hämmentävän ajankohtaisia myös tänä päivänä.

Vartolan kirjoittama ensimmäinen pääkirjoitus päättyi tammikuussa 1982 kuolleen professori Veli Merikosken muistokirjoitukseen, jossa Vartola korosti Merikosken ansioita hallinto-oikeuden ja hallinto-opillisen ajattelun kehittämisessä ja systematisoinnissa. Pääkirjoituksen päätti Merikosken Vartolalle kirjeitse välittämä, juuri perustettua Hallinnon tutkimuksen Seuraa koskeva ytimekäs viesti: "Uusi yhdistyksenne on todella tarpeellinen ja hyödyllinen. Toivotan parhainta menestystä".

Nyt ympyrä on ikään kuin sulkeutunut. Lepää rauhassa Juha.

Jussi Kivistö (päätoimittaja),

Kaisa Kurkela ja Ulriika Leponiemi (toimitussihteerit) 